\title{
Ideologia ou violência de gênero? A difícil tarefa de ser menina no Brasil do século XXI
}

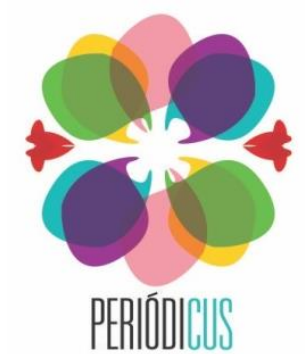

ISSN: 2358-7844

п. 12, v. 1 nov.2019-abr.2020 р. 280-309.

\author{
Luis Vinicius Belizário ${ }^{1}$
}

RESUMO: Este artigo é parte de um estudo de 2014 que teve como objetivo geral discutir o machismo praticado, reproduzido e ocultado em forma de assédio - seja moral ou sexual - dentro da escola. O ambiente escolhido foi uma instituição de ensino médio cujo público-alvo é representado por cinco adolescentes (garotas) que estudaram nesse colégio durante esse período. Tomamos essa decisão porque queríamos captar os efeitos do machismo (por meio dos assédios) sobre as garotas e entender o quanto ele impacta na população feminina da escola e, a partir desses relatos, registrar como elas lidavam com essas situações de seus cotidianos. Neste artigo, apresentaremos os relatos que apontam o quanto o ambiente educacional é opressor, machista e desigual, tratando-se da questão de gênero e, também, como o espaço da escola se torna insalubre quando essas práticas são ignoradas e ocultadas. Os dados coletados, analisados e aqui apresentados têm o objetivo de suscitar a sociedade atual a refletir sobre seu sistema de privilégios para os homens e o quanto isso é nocivo no final, já que um contingente imenso de talentos femininos se perde a cada ano, e aquelas que superam as expectativas, no final das contas, acabam sempre em desvantagem, mesmo que obtenham 'sucesso' em suas vidas, já que ocuparão, na maioria das vezes, posições inferiores às dos homens. E, mesmo que os superem, sabemos o tamanho do preço dessa superação. Dessa forma, tendo como objetivo combater esse mal secular que nos assola e buscando criar um ambiente menos insalubre e propício para que o melhor dos seres humanos aflore, apresentamos as reflexões e relatos neste artigo e convidamos todas as pessoas a pensarem uma escola melhor, o que, consequentemente, refletiria em toda a sociedade. Mas, para que isso ocorra, não poderemos, de forma alguma, negar que a desigualdade de gênero está no cerne dessas discussões e, se não a levarmos em consideração, as melhorias e mudanças jamais virão. PALAVRAS-CHAVE: Machismo. Gênero. Assédio. Escola. Práticas pedagógicas.

\begin{abstract}
This article is part of a 2014 study, whose general objective is to discuss the machismo practiced, reproduce and hidden in the form of harassment-whether moral or sexual - within the school. The environment chosen was a high school institution, whose target audience is represented by five female adolescents who studied in this college during this period. This was so that we could capture the effects of machismo on these adolescents (in the form of harassment), verify how it affects the female population of the school, and record how they handled such situations in their daily lives. This article shows reports indicating how the educational environment is oppressive, sexist and uneven with regard to gender, as well as how the school space becomes unhealthy when such practices are ignored and concealed. The data collected serve to incite modern society to reflect on its current privilege system destined for men and how it is detrimental, considering a great number of women's skill is wasted every year, wherein even those women who overcome society's expectations always end up in a disadvantageous position even when 'becoming successful', since oftentimes they will hold lower positions compared to men. Even when overcoming men, it always comes at a cost. As such, seeking to combat this ancient dread and aiming for less unhealthy environments in which the best of humankind can emerge, we present our reflections and invite people to think of a better school environment which would eventually affect all of society. However, for this to occur, we must not deny gender inequality as being the foundation of such discussion, given that otherwise improvements and change would never come.
\end{abstract}

Keywords: Male chauvinism. Genre. Harassment. School. Pedagogical practices.

${ }^{1}$ Graduado em Ciências Sociais pelo Centro Universitário Fundação Santo André. Mestre em Ciências Humanas e Sociais pela Universidade Federal do ABC (UFABC) (2018). E-mail: viniciusbelizario@yahoo.com.br 
Resumen: Este artículo es parte de un estudio realizado en 2014, el que tuvo como objetivo discutir el machismo que ocurre, reproduce y se oculta en forma de acoso, ya sea moral o sexual, dentro de la escuela. El ambiente elegido fue una escuela secundaria, y el público objetivo estuvo representado por cinco adolescentes (niñas) que estudiaron en la escuela durante este período. Tomamos esta decisión porque queríamos capturar los efectos del machismo (a través del acoso) en las adolescentes y comprender cómo impactó a la población femenina de la escuela y, a partir de estos informes, registrar cómo lidiaron con estas situaciones en sus vidas cotidianas. En este artículo, presentaremos informes que señalan cuán opresivo, machista y desigual es el ambiente educativo sobre los temas de género, y cómo el espacio escolar se vuelve insalubre cuando estas prácticas son ignoradas y ocultas. Los datos recopilados, analizados y presentados aquí tienen la intención de incitar a la sociedad actual a reflexionar sobre su sistema de privilegios para los hombres y lo perjudicial que es, ya que cada año se pierde un gran contingente de talentos femeninos, y aquellas que superan las expectativas siempre terminan en desventaja, incluso si obtienen 'éxito' en sus vidas, ya que a menudo ocuparán posiciones inferiores a los hombres. E incluso si los superan, sabemos el tamaño del precio de ese exceso. Por lo tanto, con el objetivo de combatir este mal secular que nos atormenta, y buscando crear un ambiente más saludable y propicio para que florezcan los mejores seres humanos, presentamos las reflexiones e informes de este artículo y les invitamos a todas las personas a pensar en una escuela mejor, lo que reflejaría en toda la sociedad. Pero para que eso suceda no podemos negar de ninguna manera que la desigualdad de género está en el centro de estas discusiones, y si no la tomamos en cuenta, nunca llegarán las mejoras y los cambios.

Palabras clave: Machismo. Género. Acoso. Escuela. Prácticas pedagógicas.

Periódicus, Salvador, n.12, v.1, nov.2019-abr.2020 - Revista de estudos indisciplinares em gêneros e sexualidades Publicação periódica vinculada ao Núcleo de Pesquisa NuCuS, da Universidade Federal da Bahia - UFBA

ISSN: 2358-0844 - Endereço: http://www.portalseer.ufba.br/index.php/revistaperiodicus 


\section{Introdução}

No dia 9 de novembro de 2018, o então candidato eleito e ainda não empossado à Presidência da República, Jair Bolsonaro, ao se posicionar contrário a uma questão do Exame Nacional do Ensino Médio (Enem), afirmou que exigirá conhecer previamente as questões do exame para evitar a "ideologia de gênero" e sentenciou: "quem ensina sexo é papai e mamãe e acabou, ponto final, não precisamos discutir esse assunto" (QUEM ENSINA..., 2018, não paginado), em claro alinhamento com o discurso ideológico do projeto chamado Escola sem Partido. ${ }^{2}$

O posicionamento contrário de Bolsonaro e seus correligionários às discussões de gênero nas escolas, apesar de ser diretamente direcionado à questão de lésbicas, gays, bissexuais, travestis e transexuais (LGBT+) nessa declaração, atinge não apenas a esse grupo, mas também ao público feminino, já que as críticas às denúncias de machismo e ao feminismo e o discurso misógino são bandeiras do conservadorismo atual que, claramente, foram assumidas pelo presidente ao afirmar sobre o perfil do futuro ministro da Educação: "Precisamos de um ministro que entenda que nós somos um país conservador”. (QUEM ENSINA..., 2018, não paginado)

Essas afirmações me remeteram a minha pesquisa sobre gênero, desenvolvida no final da minha especialização em Ética, Valores e Cidadania na Escola, na Universidade de São Paulo, em parceria com a Universidade de Stanford, na Califórnia (EUA).

Ao assumir a disciplina de Sociologia em uma Escola Técnica (Etec) do Centro Paula Souza, decidi trabalhar a questão de gênero com as turmas do primeiro ano do ensino médio, não somente por minha convicção de que algo mais efetivo precisava ser desenvolvido dentro das escolas, mas justamente por observar o quanto as relações entre homens e mulheres, de modo geral, dentro do colégio reproduziam o que ocorria fora dos muros da escola.

Os resultados foram surpreendentes. O ambiente que se dizia "respeitoso e harmonioso" virou um campo de batalha com manifestações machistas e misóginas declaradas em salas de aula e redes sociais. Professores se manifestaram contra os cartazes que foram espalhados

\footnotetext{
2 “A questão de gênero tem sido atacada em razão do levante conservador, heteronormativo e machista que persiste na sociedade. O uso do termo 'ideologia de gênero', demonizado pelo conservadorismo do Escola Sem Partido, vislumbra carregar de preconceito e de negatividade uma questão histórica, social e política que implícita e explicitamente faz parte da prática social e educacional. A tentativa de silenciamento da questão de gênero é política e, por isso, é preciso debatê-la, de modo a ressaltar a relevância da questão. Tal tentativa de censura vai contra a liberdade e o pluralismo, valores que o Escola sem Partido afirma defender". (BALDAN; FREITAS, 2017, p. 3) 
pelos corredores da escola e alunos se sentiram ofendidos com os dizeres dos cartazes afixados pelos corredores.

Todos esses fatos me forneceram a certeza do quanto era necessário trabalhar tal problemática, pois a escola se mostrou totalmente despreparada para a questão, e eu, muitas vezes, totalmente isolado ao levantar essa bandeira e, em alguns momentos, até coagido.

Com isso, este trabalho buscou conhecer as implicações e impactos do machismo praticado no cotidiano e que se manifestavam dentro da escola em forma de assédio (seja sexual ou moral) sobre as alunas do ensino médio e apontar de que maneira elas lidavam com essas situações.

O que apresentamos neste artigo é apenas parte da pesquisa realizada em 2014. Relatos de cinco alunas servirão como base para apontarmos o machismo e o sexismo que ocorre dentro da escola e de que forma esse machismo se vale de toda uma estrutura de desigualdade e opressão para, ainda, fornecer aos homens o privilégio do assédio, seja sexual ou moral.

Assim, para empreender melhor a pesquisa, utilizamos as teorias de Assis e Avanci (2004), Figueiredo (2006), Faludi (2001), Koehler (2002), Macedo e Bomfim (2007), Moraes e Belizário (2005), Teixeira e Porto (1998), Wolf (1992), Vanier (2006), Viana e Ridenti (1998) e Walkerdine (1995).

Para garantirmos consistência ao estudo do tema, que carrega enorme complexidade, buscamos as contribuições de estudos com densidade e profundidade que apontassem os essenciais aspectos dentro daquilo que nos propusemos a discutir e problematizar com este trabalho. Dessa forma, nossa fundamentação teórica conquistada com a rica contribuição dos autores/as mencionados nos permitiu atingir os objetivos previamente estabelecidos.

\section{Descrição da área de estudo}

A escola onde esta pesquisa foi realizada foi fundada nos anos 1950 como uma escola industrial. Situada na região oeste de São Paulo, inicialmente oferecia cursos ao público feminino, como os de Economia Doméstica e Corte e Costura. Com o passar dos anos, foi mudando não somente sua denominação, mas também os cursos oferecidos e, consequentemente, seu público.

O bairro onde a escola está situada, inicialmente, apresentava característica popular, mas hoje está se consolidando como uma região de apartamentos para a classe média. A prefeitura de 
São Paulo vem promovendo um intenso processo de verticalização no bairro e eliminando de forma rápida os galpões industriais que anteriormente eram comuns por toda a região. A aceleração do processo de expansão imobiliária é visível e não é difícil nos admirarmos com os edifícios modernos de apartamentos residenciais que estão se espalhando rapidamente.

Atualmente, o público da escola é majoritariamente masculino quando se trata dos cursos técnicos, mas estes ocorrem à noite. No ensino médio, mesmo os cursos oferecidos sendo socialmente pensados para o público masculino, percebe-se cada vez mais garotas aumentando o contingente das salas de mecatrônica, logística e informática.

Mais de 25\% dos/as alunos/as têm renda familiar acima de seis salários mínimos e apenas 8\% vivem com renda familiar de um salário mínimo. Existe um incentivo ao corpo docente para o desenvolvimento de ações socioconstrutivas, nas quais a comunidade escolar se envolve em projetos multidisciplinares, culturais, sociais, pesquisas e olimpíadas. Os alunos e alunas também participam ativamente do grêmio estudantil e de muitos outros projetos e programas em que podem desenvolver o protagonismo e exercitar o processo de autodesenvolvimento.

\section{Metodologia}

Esta pesquisa teve caráter qualitativo, pois buscou, por meio de entrevistas semiestruturadas, captar e transcrever os sentimentos de cinco alunas (Lara, Maria Flor, Naomi, Valentina e Fernanda) envolvidas nos constantes assédios dentro da escola, a forma como se comportavam perante a postura da instituição de ensino relacionada a essas práticas e a todas as regras que regiam homens e mulheres dentro do espaço escolar.

Considerando nosso conhecimento prévio e tudo o que levantamos, nosso objetivo foi o de produzir informações de qualidade e reflexões profundas, conforme apontam Gerhardt e Silveira (2009). Estamos cientes das críticas às quais as pesquisas qualitativas estão predispostas, já que seu caráter subjetivo é fortemente marcado e o envolvimento emocional do/a pesquisador/a fica evidente nesse perfil de pesquisa, conforme nos diz Minayo (2001). Particularmente, esse é o nosso caso, já que lecionamos e temos informações das entrevistadas que vão para além daquelas captadas durante a entrevista.

Por outro lado, o autor nos explica que esse tipo de pesquisa trabalha com um universo de significados, crenças, valores, aspirações, motivos e atitudes que correspondem a um espaço 
mais profundo dos processos, fenômenos e relações que de forma alguma podem ser reduzidos às simples operacionalizações de variáveis. (MINAYO, 2001) Ela seria um contraponto à pesquisa quantitativa e, originalmente, foi aplicada em estudos sociológicos e antropológicos, mas, atualmente, tem ampliado seu campo de atuação para áreas da psicologia e da educação.

\section{A difícil tarefa de ser menina}

Para uma melhor análise de tudo o que havia ocorrido na escola envolvendo essas garotas e todas as outras coisas que estavam ocorrendo, tornou-se necessário muito mais do que uma breve introdução descritiva do perfil de cada uma delas, principalmente pelo fato de nossa abordagem não ser de âmbito analítico na esfera da psicologia. O que buscamos com a pesquisa, apesar de evidenciar os sentimentos dessas garotas, foi de fato explicitar as más condições sob as quais elas estavam inseridas e como isso não é colocado como problema estrutural a ser eliminado, justamente pela nossa formação e visão machista de mundo.

Conhecendo a limitação de nossa pesquisa, a melhor maneira que encontramos de evidenciar quem realmente seriam essas garotas, quais suas visões de mundo perante a vida, suas influências, crenças, valores e posicionamentos políticos, foi incluir no questionário desenvolvido para as entrevistas uma pergunta que diretamente extraísse delas o que desejávamos. Com isso, formulamos o seguinte questionamento: "Me fale um pouco sobre o que é ser uma adolescente - do sexo feminino - para você”. A resposta de Lara foi:

\footnotetext{
É um desafio, porque tem imposições de todos os lados, tem as cobranças comuns que cabem a todos os adolescentes homens ou mulheres, mas tem cobranças além, pois é logo nesta fase que começa o 'estar sempre bonita', 'estar bem arrumada, ter que lidar com comentários como 'você não segue o padrão'... É, eu tenho uma certa sorte por eu ser magra, mas, mesmo assim, eu ainda sofro, porque eu sou muito magra, e aí eu não atendo ao padrão, que é o da mulher gostosona e tal. E ai recebe o apelido de 'palito de fósforo' e essas coisas. Então é pressão atrás de pressão e, além dos estudos e das responsabilidades, ainda tem que se preocupar com estas coisas. (Lara - 10/09/2014)
}

É interessante o final da frase de Lara, quando ela diz que, "além dos estudos e das responsabilidades, ainda tem que se preocupar com estas coisas". Nota-se que ela minimiza e reduz a questão da pressão pela "beleza" ao utilizar a afirmação "estas coisas". Comumente, fazemos isso em nosso cotidiano, "a beleza", "o estar bonita", "arrumada", "bem vestida e dentro da moda", a pressão pelo "corpo perfeito" - tudo está naturalizado em nosso dia a dia e 
não notamos essas práticas. Ninguém melhor do que Naomi Wolf para explicar e decodificar o que ela denomina de "O mito da beleza", uma criação machista e que tem a função de aprisionar as mulheres.

\begin{abstract}
Na regressão dos anos 1950, por pouco tempo as formas cheias naturais à mulher puderam ser apreciadas mais uma vez, porque as mentes dessas mulheres estavam ocupadas na reclusão doméstica. No entanto, quando as mulheres invadiram em massa as esferas masculinas, esse prazer teve de ser sufocado por um urgente dispositivo social que transformaria os corpos femininos nas prisões que seus lares já não eram mais. (WOLF, 1992 p. 243-244)
\end{abstract}

Depois da Segunda Guerra Mundial, as mulheres ocidentais não se permitiram mais viver na reclusão de seus lares sob o controle absoluto dos homens. Elas foram cruciais durante a grande guerra - seja no front ou nas indústrias -, perceberam o quanto a sociedade dependia da sua participação efetiva na economia e na vida social. E o "sabor da liberdade", mesmo que não em sua plenitude, promoveu os movimentos de luta e resistência do feminismo surgido em meados do século XX. Esse espaço ocupado por elas desde então passou a incomodar os homens que até aquele momento controlavam sem qualquer objeção a família e o mercado.

Esse incômodo permanece até hoje, mas o modelo patriarcal encontrou outra forma de se manter nas redes da sociedade e essa lógica, hoje, está estabelecida nas relações sociais de maneira que muitos não percebem, já outros não aceitam discutir, principalmente nas escolas.

Estabelecer um padrão de beleza a ser seguido já é, por si só, uma violência à essência da natureza e da humanidade, que tendem a ser diversas. Agora, impor que esse padrão seja seguido desde a infância e adolescência é uma lesão ainda maior à individualidade do ser, já que, na maioria dos casos - considerando a nossa sociedade -, o padrão de beleza exaltado e exigido das mulheres é praticamente impossível de ser atingido, ou seja, criar mais uma preocupação para essas garotas que estão vivendo uma fase complexa de mudanças hormonais e físicas é realmente violentá-las.

Podemos afirmar que garotas iniciam suas vidas com uma imensa desvantagem em relação aos garotos nesse aspecto, já que não paira essa pressão sobre eles. Qualquer pesquisa que aponte um menor desempenho de garotas em atividades acadêmicas, esportivas e na vida cotidiana de forma geral deverá levar em consideração essas questões, caso contrário, os dados 
serão tão perversos e mal-intencionados quanto a sociedade que eles representam. Quando falamos com Maria Flor, sua resposta para a mesma pergunta foi a seguinte:

Então, eu acho que ser uma adolescente mulher, principalmente na sociedade onde a gente vive, é muito difícil, porque, ao mesmo momento, você é pressionado por pessoas de qualquer idade a ser uma pessoa que você não é. Eles não deixam você ser, você crescer ou descobrir quem você é. Se você começa a namorar e não transa, você é criança, se você transa, você é vadia - a gente não tem escolha. Se a gente usa short na escola, não pode, os professores não deixam, mas os meninos podem usar; se a gente usa shorts curto, a gente tá pedindo pra ser abusada... É... Se as meninas ficam com vários meninos, elas são vadias, e se os meninos ficam, eles são os garanhões. Então qualquer ato que você fizer, você está predisposta a ser julgada pelo fato de você ser mulher. Atividades preestabelecidas só pra homens e pra mulheres... É muita coisa que já começa desde adolescente. (Maria Flor - 10/09/2014)

Maria Flor, assim como Lara, considera muito difícil a vida de uma adolescente mulher e sua fala está permeada da pressão social que sofre. É marcante a falta de autonomia e respeito destinado às garotas quando ela afirma: "Eles não deixam você ser, você crescer ou descobrir quem você é".

É de uma angústia sufocante quando sentimos que não podemos nos expressar ou sermos nós mesmos, e o desabafo de Maria Flor expõe justamente isso, esse impedimento sádico que a nossa sociedade estabelece sobre os adolescentes de modo geral, mas que as garotas sentem de forma muito mais incisiva e cruel. Isso compromete a qualidade de vida, o aprendizado e o pleno desenvolvimento dessas adolescentes. Moraes e Belizário (2004) têm algo a dizer sobre essa questão:

Isso é ruim para seu aproveitamento, pois não existe a possibilidade de um ser humano represar uma parte de si mesmo e ainda assim se expressar plenamente, já que parte de seus recursos está dentro da fração desprezada. (MORAES; BELIZÁRIO, 2005, p. 33)

A questão da sexualidade é outro ponto marcante, desde o vestuário reprimido pela própria escola - o que não acorre com os garotos - e a concepção machista de que uma mulher com roupa curta está provocando e "pedindo para ser abusada", até a própria relação sexual em si. Como bem colocou Maria Flor, "a gente não tem escolha”. A questão sexual é bem cara para as mulheres e, quando ainda se é uma garota, o custo de tudo isso se amplia ainda mais. Quando lemos informações que apontam o quanto as mulheres têm dificuldades em atingir o 
orgasmo em comparação aos homens, a quantidade de mulheres que não se sentem bem na cama e as muitas outras que sequer consideram a possibilidade de que o sexo seja algo prazeroso e sem tabus tem completa ligação com o modo como educamos nossa sociedade.

\begin{abstract}
O impulso sexual é formado pela sociedade. Até mesmo os animais têm de aprender o comportamento sexual. Os antropólogos acreditam atualmente que é o aprendizado, mais do que o instinto, que leva a um comportamento reprodutivo bem-sucedido. Macacos criados em laboratório são ineptos no que diz respeito ao sexo, e os seres humanos também precisam aprender o seu comportamento sexual a partir de sugestões externas. (WOLF, 1992, p. 174)
\end{abstract}

Acreditamos que a melhor forma de concluirmos a fala de Maria Flor é utilizando a ideia de uma de suas próprias afirmações. Uma mulher está predisposta a ser julgada pelo mero fato dela simplesmente ser uma mulher! Naomi também externa esta mesma angústia diante de todas as limitações:

Eu lembro que, desde os meus dez anos de idade, eu já tinha a consciência de que seria bem melhor pra mim ser um menino. Eu não lembro exatamente como eu tomei consciência disso, mas assim [...]. Seria bem melhor se eu fosse um menino, porque eu iria poder correr, iria poder suar... não iria precisar me arrumar muito. (Naomi 11/09/2014)

Percebam que a fala dela está carregada de informações sobre a nossa tradicional divisão do trabalho, ou seja, atividades que são destinadas aos meninos e as que são feitas para as meninas. Desde os dez anos de idade, Naomi já sente essa diferença, já sabe que é "melhor" ser um garoto, já identifica que existem vantagens em ser um menino e percebe que, de alguma forma, o cuidado que ela tem de dispensar à "sua beleza" compromete outras esferas da sua vida. Susan Faludi (2001), em Backlash: o contra-ataque na guerra não declarada contra as mulheres, diz:

Podem dizer à vontade que as mulheres foram 'liberadas', mas não é bem isto que as próprias mulheres pensam. A maioria das mulheres vem repetindo constantemente, em pesquisas nacionais, que ainda estão muito longe da igualdade. (FALUDI, 2001, p. 14)

Naomi, aos dez anos de idade, já sentia isso, mas seu saber não estava somente ligado aos livros infanto-juvenis que ela já havia lido, conforme revelou em entrevista. Ela lia essa diferença em seus livros e comprovava os fatos na realidade de seu cotidiano. Considerando agora os aspectos humanos de empatia e solidariedade, identificar que uma garotinha aos dez 
anos de idade já conseguia perceber sua desvantagem perante o mundo é, no mínimo, muito triste de se constatar.

Valentina discursa sobre a mesma problemática que apresentaram suas amigas em relação a ser uma adolescente menina. Responsabilidades, a questão sexual e a falta de respeito são pontos citados por ela com a mesma eloquência e conhecimento de causa de suas colegas, conforme veremos em sua fala:

Ser adolescente já não é muito fácil, porque a gente está em uma fase onde a gente tem responsabilidade de adulto e acaba sendo tratada como um não adulto ainda. Não como uma criança, mas não somos tratadas como um adulto sério e, ainda mais, mulher. A mulher não é ouvida, a menina está reclamando demais, se você é adolescente e pegar muitos meninos na escola, você é vagabunda, isso e aquilo. É complicado. Principalmente agora, que a gente sabe sobre os problemas que a gente passa, que a gente conhece o feminismo e tal, acaba ficando uma carga maior, porque, quando você está na ignorância, dói menos do que você saber o problema que você está passando, entendeu? Então assim, é bem difícil. (Valentina - 11/09/2014)

Valentina, como já citado, tem conhecimentos sobre feminismo, gosta de ler sobre essas questões e evidencia isso em sua fala. Justamente por ter esses conhecimentos, explicita o que suas amigas anteriormente ainda não haviam abordado - a "dor" que, muitas vezes, o conhecimento pode nos proporcionar.

Em Matrix, o aclamado clássico de ficção científica das irmãs Wachowsky, essa discussão está presente em uma das cenas mais antológicas da película. Cypher, um dos integrantes da nave Nabucodonosor, não aguenta mais a realidade e decide trair seus amigos de resistência em troca de esquecer tudo o que viveu até aquele momento. O filme conduz uma discussão filosófica, política, sociológica e até religiosa, mas, nessa cena em específico, quando Cypher está sentado a uma mesa de restaurante com Smith, sua fala questiona a realidade ou o que poderia ser ou não real.

Valentina ainda nem falava quando o filme estourou em sucesso mundo afora e, até aquela data (2014), não havia assistido por inteiro e muito menos refletido sobre a proposta das diretoras. Mas, ao dizer que "quando você está na ignorância, dói menos do que você saber o problema que você está passando", ela expressa perfeitamente o que as diretoras e roteiristas do clássico se propuseram a transmitir ao público.

Periódicus, Salvador, n.12, v.1, nov.2019-abr.2020 - Revista de estudos indisciplinares em gêneros e sexualidades Publicação periódica vinculada ao Núcleo de Pesquisa NuCuS, da Universidade Federal da Bahia - UFBA ISSN: 2358-0844 - Endereço: http://www.portalseer.ufba.br/index.php/revistaperiodicus 
Em relação à realidade das mulheres nesse mundo, assim como Cypher, elas pedem por socorro. O "Judas Iscariotes" da ficção de maior sucesso mundial do final do século XX está tão desesperado com a dura realidade em que vive que decide trair não somente seus amigos, mas seus ideais e o pouco que resta de seres humanos no planeta, na tentativa de aliviar sua dor em saber o quanto a vida é difícil e impiedosa.

Cypher faz um pacto com Smith e promete entregar Morpheus - o líder dos rebeldes para o vilão e, em troca, deseja esquecer tudo, retornar para a Matrix (mundo dos sonhos e da simulação) e ser alguém famoso e muito rico. Ele conclui o diálogo comendo um pedaço de bife, filosofando saber que aquele pedaço de carne não é real, mas a ilusão que o seu cérebro proporcionava a ele ao comer; "aquela simulação do real" era tão prazerosa que, para ele, a ignorância era uma dádiva maravilhosa.

Qual a diferença entre Cypher e Valentina? Se desconsiderarmos que o primeiro é uma personagem de um filme, a diferença entre ambos é que Cypher, em sua realidade, pode deixar de ver e viver o sofrimento do cotidiano e mergulhar em uma vida alienada, já Valentina, não! Ela jamais deixará de ver e sentir o mundo como ele é, ela não pode, com facilidade, deixar de ser uma mulher e, mesmo que consiga, as consequências não serão tranquilas, e muito menos conseguirá ignorar a violência sofrida todos os dias. De alguma forma, Cypher traduz para os cinemas de todo o mundo uma frase dita por John Winston Lennon: “A ignorância é uma espécie de bênção; se você não sabe, não existe dor”.

Valentina não é fã dos Beatles - pouco conhece as músicas de Lennon - e sequer assistiu direito ao Matrix, mas sua fala está em plena sintonia com ambos e nos faz refletir sobre algo que não desejamos, mas que dia e noite oprime as mulheres e que, de um jeito ou de outro, fornece (muitos) privilégios e vantagens aos homens.

Fernanda foi a última a ser entrevistada e, por isso, muitos de seus apontamentos reprisam aquilo que suas amigas anteriormente já haviam dito. Por um lado isso é bom, pois indica pontos comuns nas falas das garotas com os quais comumente não nos importamos. Ela aborda a questão da visão que o feminismo forneceu a ela, os problemas cotidianos da escola, a vulnerabilidade que alguns pensam ser inerentes ao sexo feminino e o desrespeito quase "natural" de muitos homens. Mas o que se destaca na fala de Fernanda das outras e que gostaríamos de evidenciar é a questão do medo:

Periódicus, Salvador, n.12, v.1, nov.2019-abr.2020 - Revista de estudos indisciplinares em gêneros e sexualidades Publicação periódica vinculada ao Núcleo de Pesquisa NuCuS, da Universidade Federal da Bahia - UFBA ISSN: 2358-0844 - Endereço: http://www.portalseer.ufba.br/index.php/revistaperiodicus 
Assim, eu acho que, antes de eu conhecer o feminismo, eu não tinha tanta noção dos problemas e de quanto é, às vezes, ruim ser uma mulher, porque... É óbvio que a gente se incomoda muito com os assédios na rua, que a gente vive com medo de quando a gente anda sozinha na rua, porque assim, o homem vive com medo, às vezes, de andar na rua à noite e ser assaltado, mas uma mulher não. Uma mulher pode ser assaltada, pode ser estuprada, ela pode ser violentada. Então assim, comparando uma pessoa do sexo masculino, um adolescente do sexo masculino, você vê que muitas coisas do que a gente sofre na escola e na rua é só por ser uma mulher, que a gente sofre, e muitos homens que andam na rua não sofrem assédio e não têm noção desse medo, do que é ser mulher. E na escola também, porque os maiores problemas que a gente tem é por ser menina, porque os professores, por serem homens, parecem que 'ah, porque é mulher, eu não vou respeitar, é menina, é fraca, sensivel'. Assim, talvez, a diferença de ser uma mulher e ser uma adolescente talvez seja esta questão de respeito mesmo, sabe? eu acho que às vezes os homens veem umas meninas e falam: 'ah, essa é mais frágil e não sei o quê'. Então eu acho que o principal de ser uma adolescente menina é esta coisa mesmo, do machismo que a gente sofre o tempo todo em várias questões da nossa vida. (Fernanda - 11/09/2014)

É marcante em sua fala a situação de medo e insegurança que vive constantemente, principalmente no trecho que afirma: "muitos homens que andam na rua não sofrem assédio e não têm noção desse medo, do que é ser mulher". O medo por si só é algo inerente a nós, humanos, e à maioria dos outros seres. Ele nos ensina, protege, faz que cuidemos melhor de nossas vidas e nos livra de contratempos, perigos e outras mazelas. Por outro lado, suas consequências podem ser desastrosas dependendo do contexto em que ele ocorre. O medo, em sua versão patológica e a longo prazo, acarreta o impedimento de crescimento pessoal, diminui a capacidade de interação com as pessoas, comprometendo relações, autoestima e leva o indivíduo ao adoecimento, como explicado por Teixeira e Porto:

O imaginário do medo ocupa um espaço material no corpo, ou seja, tem uma inscrição corporal, porque, além de ser provocado por ameaças externas reais ou imaginárias às imagens da angústia original devida à emergência da consciência do Tempo e da Morte, e às experiências negativas advindas dessa consciência. (TEIXEIRA; PORTO, 1998, p. 54)

Como dissemos, o medo é algo que não se separa de nós, mas seus objetos têm uma determinação histórica e social. Assim, se o medo ultrapassa a esfera da naturalidade e toma no corpo do amedrontado uma dimensão para além do aceitável, assim como sua determinação histórica e social foi estabelecida, temos um compromisso ético de movermos as organizações

Periódicus, Salvador, n.12, v.1, nov.2019-abr.2020 - Revista de estudos indisciplinares em gêneros e sexualidades Publicação periódica vinculada ao Núcleo de Pesquisa $\mathrm{NuCuS}$, da Universidade Federal da Bahia - UFBA ISSN: 2358-0844 - Endereço: http://www.portalseer.ufba.br/index.php/revistaperiodicus 
sociais - que também são historicamente determinadas - para combater essa manifestação criada pelas relações de poder que envolvem a questão de gênero.

A abordagem que desenvolvemos nesta parte de forma alguma tinha como pretensão esgotar os elementos levantados nesta análise. Apenas desejamos levantar informações das próprias garotas que apontassem para os inúmeros levantamentos que indicam, denunciam e quantificam a existência do machismo em nosso cotidiano. Todas as entrevistadas, cada uma a sua maneira, apontaram e corroboraram com algumas das teorias existentes e citadas por nós.

Mas, para além disso, gostaríamos de elencar cinco pontos importantes que as garotas trouxeram em suas falas e sobre os quais não poderemos nos aprofundar por não ser esse o objetivo deste trabalho. O 'medo' trazido por Fernanda, em que o simples caminhar pelas ruas se torna algo aterrorizante para ela e incompreendido pelos homens. A 'privação' que Naomi explicita ao não poder brincar da forma que os meninos brincam e toda sua frustração desde os seus dez anos de idade. A 'repressão' sexual, claramente descrita por Maria Flor, e a 'impossibilidade' de ser ela mesma, já que as interferências, orientações e o controle das pessoas sobre a vida de uma menina são grandes; a normatização estética e de indumentárias e adornos relatada por Lara ao falar sobre a pressão que as meninas sofrem para se manterem 'bonitas'; e, por último mas não menos importante, a ignorância e a alienação tão polêmicas citadas por Valentina. Ela relata que o feminismo abriu seus olhos para algo que, no fundo, hoje lhe provoca muita dor. Valentina abre um precedente filosófico para a discussão sobre ignorância/alienação e conhecimento. Seria melhor não saber sobre todas essas desvantagens, já que a desigualdade é um fato?

Enfim, são cinco elementos desse universo que não trabalharemos, mas que acabamos por desvelar mesmo não tendo a intenção. Deixamos aqui o caminho para que outras pessoas prossigam, criem novas abordagens e revelem novas dinâmicas que certamente ainda estão camufladas pela sutileza letal do machismo. O nosso objetivo, neste momento, é avançarmos em direção ao interior das instituições de ensino e analisarmos os fatos à luz das falas dessas alunas e dos pesquisadores/pesquisadoras que temos como base para trabalharmos a questão das ocorrências de machismo em forma de assédios.

Conforme averiguado, o universo das meninas é permeado de medo e violência (física, verbal e psicológica), e não é possível viver de forma plena dessa maneira, como inclusive apontam Macedo e Bonfim (2007). Esse medo e essa violência certamente conduzem as meninas 
a um círculo negativo em que a baixa autoestima fará parte de todos os males ali envolvidos, assim como Assis e Avanci (2004) nos apontou. Portanto teremos uma hierarquização entre os gêneros e isso é extremamente nocivo, segundo Valerie Walkerdine (1995).

Para eliminarmos essa produção que mina a autoestima e promove hierarquização entre os gêneros, Vianna e Ridenti (1995) nos orientam sobre a forma como devemos trabalhar essa questão de gênero na escola, e Rosenberg (1989) também nos alerta para as formas de combater essa desigualdade que ocasiona a baixa autoestima. Orientados por tais teorias é que estruturamos nosso trabalho sobre a discussão de gênero, já que tínhamos o intuito de propor a mais assertiva forma metodológica/curricular a ser trabalhada nas escolas para reduzir e eliminar essas desigualdades.

\section{Assédio e ambiente escolar}

Antes de iniciarmos nossa abordagem sobre os assédios ocorridos dentro da escola, é válido frisar que as formas de assédio, em sua grande maioria, não acontecem de modo declaradamente explícito. Em sua grande parcela de vezes, elas vêm de modo não óbvio, não declarado e velado, em forma de piadinhas, outras vezes como um excesso de pressão e cobrança, ameaças latentes, brincadeiras depreciativas e inconvenientes. Essas são algumas das formas mais clássicas do assédio.

Isso precisa ser observado muito seriamente pelas instituições de ensino e suas instâncias superiores, pois estamos falando aqui de um ambiente que acolhe e forma as futuras gerações de uma nação e, se desde a sua formação lhes faltam integridade, ética e um ambiente saudável, o que podemos esperar dos ambientes educacionais futuros, assim como da sociedade que está em construção? Tudo aquilo que plantamos hoje certamente será colhido amanhã, portanto precisamos encarar os ambientes escolares com um canteiro repleto de mudas e sementes, o que irá florescer amanhã depende do nosso 'cuidar' hoje. Wagner Sant'Anna Figueiredo resume bem isso ao afirmar que:

Levando em conta que na unidade escolar há uma hierarquia administrativa, o corpo docente, a equipe técnica e os elementos de apoio precisam conviver de forma harmoniosa no sentido de proporcionar paz para que a construção do conhecimento aconteça. Do contrário haverá um dano à sociedade. A comunidade escolar é ampla, mas se faz necessário que ultrapasse as questões específicas de cada área e esteja voltada para o crescimento do alunado de maneira integral. (SANT'ANNA FIGUEIREDO, 2006, p. 35) 
Durante os nossos levantamentos, identificamos que, além dos casos de assédio moral algo comum e corriqueiro no ambiente escolar -, as garotas demonstraram que o assédio sexual era algo que as incomodava muito mais do que o primeiro. Acreditamos em duas hipóteses para que haja maior incômodo com o segundo. A primeira é que, por ser muito mais banalizada e frequente a questão do assédio moral, as alunas já estejam 'habituadas' e doentiamente naturalizadas a esse tipo de violência, por isso sabem lidar melhor com esse desvio de conduta. É claro que isso não tira a gravidade da situação, pois, se uma forma de opressão e violência se torna natural e parte do cotidiano, algo de muito errado está ocorrendo e isso exige medidas drásticas e urgentes de correção.

A segunda hipótese é justamente a questão do conhecimento sobre a violência. Como já vimos, de alguma forma nossas entrevistadas- em maior ou menor escala - conhecem os princípios básicos do feminismo, assim como suas lutas e reivindicações clássicas. Desse modo, como bem colocou Valentina em suas falas, além de dolorosa, a realidade se torna insustentável, e a alternativa é lutar contra ela de alguma maneira. Seja se negando e tentando se tornar 'invisível' e imperceptível (como nos revelou Lara em outro momento da entrevista, ao dizer que sentia vontade de vir vestida de uma forma que não chamasse de forma alguma atenção do professor), resistindo e se organizando - conforme relatamos em outras partes da pesquisa não disponibilizadas neste artigo - ou denunciando, como veremos a seguir.

Para entendermos como o ambiente escolar era visto e sentido pelas garotas, elaboramos a seguinte pergunte: "Em sua opinião, existe alguma diferenciação no tratamento de meninos e de meninas por parte da escola"? (Seja em relação ao currículo escolar ou por parte dos professores).

A intenção era justamente descobrir se elas notavam alguma diferenciação no tratamento de meninos e meninas e, com isso, tentarmos associar as práticas e regras escolares com um machismo naturalmente aceito e inserido em nossas atividades cotidianas. $\mathrm{O}$ outro aspecto era identificarmos se, por acaso, tudo aquilo que se ouvia como boato pelos corredores envolvendo a polêmica sobre assédio sexual e o corpo docente seria encontrado em seus relatos. Sobre a diferenciação entre meninos e meninas, Lara afirmou:

Com certeza! Dá pra ver principalmente no técnico. Como eu faço informática e é uma área mais voltada pro público masculino, não tem muitas mulheres na área e muitos professores fazem diferença no tratamento [...]. Quando algum programa dá erro, se uma menina vai sugerir a solução, muitos professores nem dão atenção, nem escutam direito $e$ não deixam a menina se juntar com eles pra tentar resolver. Ela é sempre deixada de lado e Periódicus, Salvador, n.12, v.1, nov.2019-abr.2020 - Revista de estudos indisciplinares em gêneros e sexualidades Publicação periódica vinculada ao Núcleo de Pesquisa NuCuS, da Universidade Federal da Bahia - UFBA ISSN: 2358-0844 - Endereço: http://www.portalseer.ufba.br/index.php/revistaperiodicus 
ninguém escuta o que ela tem pra falar e, às vezes, ela tem a solução correta. O que a impediria de não ter? (Lara - 10/09/2014)

Mais chocante do que seu relato é sua indagação, pois ela nos faz pensar qual seria a real condição que levaria um professor a impedir a participação de uma aluna em um processo de decisão em meio a um universo de maioria masculina. Se um professor tem o compromisso e o objetivo maior de proporcionar a seus alunos e alunas um pleno desenvolvimento acadêmico, essa forma de agir é totalmente desaprovada e demonstra um favoritismo aos garotos em detrimento das meninas.

A condição aplicada pelo professor nesse caso é extremamente determinista, ultrapassada e não condiz com as formas atuais de educação. Sobre essa maneira inapropriada de educar e pensar a sociedade atual, vejamos o que Vianna e Ridenti têm a nos dizer:

O determinismo biológico seria definidor das desigualdades entre mulheres e homens, tendo a medicina e as ciências biológicas como importantes aliadas que, durante muito tempo, subsidiaram as normas sociais quanto às relações de gênero. Também a antropologia combinou muitas vezes uma explicação funcionalista das sociedades coletoras-caçadoras com uma explicação evolucionista do homem, para justificar a diferença sexual, na qual o homem teria uma composição biológica mais apropriada à caça e as mulheres ao cuidado dos filhos e à coleta de alimentos. Isto é, a força física masculina e uma 'inata' capacidade de liderança habilitariam o homem para proteger e garantir o sustento da família. A mulher, por sua vez, é referenciada pela maternidade, como se sua vida só se explicasse pelo desempenho dessa função essencial, inerente à sua condição de fêmea, sendo, portanto, nutridora, maternal e habilitada para criar os filhos; diferenças essas que acabam se estendendo a outros campos por intermédio de mecanismos ideológicos. (VIANNA; RIDENTI, 1998, p. 97-98)

É um absurdo, em pleno século XXI, ainda encontrarmos um tratamento tão retrógrado e ultrapassado sendo aplicado de forma tão aberta. Pior que isso é que, pelo relato de Lara, a situação nos parece bem naturalizada entre todos e todas. Outro ponto crítico que Lara expôs em sua fala foi sobre as aulas de educação física. Essa sua afirmação é unânime entre todas as entrevistadas. Todas fizeram o mesmo apontamento em relação à diferença no tratamento entre meninos e meninas. Vejamos o que disse Lara sobre a educação física no dia 10 de setembro de 2014: "Em aulas de educação física, as meninas não podem usar shorts porque eles falam que vai aguçar a mente dos meninos. Mas tem menino que faz aula de cueca, literalmente. Semana passada eu vi uma aula de educação física, e um menino estava de cueca!".

Periódicus, Salvador, n.12, v.1, nov.2019-abr.2020 - Revista de estudos indisciplinares em gêneros e sexualidades Publicação periódica vinculada ao Núcleo de Pesquisa NuCuS, da Universidade Federal da Bahia - UFBA ISSN: 2358-0844 - Endereço: http://www.portalseer.ufba.br/index.php/revistaperiodicus 
Após essa declaração, perguntamos: “mas aí não aguça a mente das meninas?”, e Lara nos respondeu rindo e de maneira muito irônica: "Não, não aguça!" e, logo na sequência, ela emendou:

Para a aula de educação física tem que se trocar né, e tem menino que se troca na sala, e não importa quem tá lá, na frente das meninas. E não importa quem fale. Eu disse: 'cara, vai pro banheiro, tem banheiro, é pra isso e tal'; 'não, pra que ir pro banheiro? Eu posso fazer isso aqui mesmo', ele falou. (Lara - 10/09/2014)

Naomi também faz suas observações quanto a esse favoritismo dos garotos na escola:

Eles podem tirar a camiseta, que ninguém reclama. Em sala de aula não, mas lá fora eles tiram a camiseta, e a gente tem que ficar assim, apertadinha, nem pode cortar muito a camiseta do uniforme. Este é um dos tratamentos, e os professores sempre têm aquilo de: 'ah, mas esta é uma coisa mais delicada e as meninas é que vão fazer, ou isso é coisa de macho'. Assim, não é muito específico, de 'vamos separar meninos e meninas', mas a gente percebe na fala, no dia a dia, uma diferenciação de tratamento. (Naomi - 10/09/2014)

Maria Flor também comenta sobre esse favoritismo para os meninos, do qual as meninas não desfrutam:

\begin{abstract}
Muito, muito, muito! A partir do momento que na educação física as meninas têm que usar calça e os meninos podem usar shorts, porque já aconteceu isso comigo e a professora falou que os meninos iriam ficar olhando pra minha perna, mas as meninas também olham para as pernas dos meninos ou, sei lá, por esse motivo eu não posso usar short? (Maria Flor - 10/09/2014)
\end{abstract}

Perguntamos como seria esse olhar das meninas para as pernas dos meninos e Maria Flor respondeu: "É, também. Eu acho que é igual, é natural, não é aquela coisa de abuso olhando e desejando, é apenas um olhar". E, ainda permanecendo na questão da educação física, ela completou: "E aí eu fiz de propósito, coloquei uma samba-canção e a professora não deixou eu fazer. E a professora passar futebol pros meninos e as meninas não poderem jogar, só podem vôlei e outros jogos".

São tantas coisas sem sentido, que é quase impossível que as meninas não se revoltem. Imaginem no verão, essa regra prevalecendo? Garotos livres da desidratação e da perda excessiva de líquidos enquanto as meninas se derretem dentro de calças, justamente para evitar o olhar dos garotos? Por qual motivo os garotos não podem olhar? E qual seria o motivo de permitir que as garotas observem os garotos? Será que existe alguma concepção prévia sobre a libido de ambos os

Periódicus, Salvador, n.12, v.1, nov.2019-abr.2020 - Revista de estudos indisciplinares em gêneros e sexualidades Publicação periódica vinculada ao Núcleo de Pesquisa NuCuS, da Universidade Federal da Bahia - UFBA ISSN: 2358-0844 - Endereço: http://www.portalseer.ufba.br/index.php/revistaperiodicus 
sexos? E em relação ao desempenho? Será que o desempenho dos garotos não se torna melhor por conta disso? E a divisão nos esportes?

Ficamos nos perguntando, se a alemã Nadine Angerer, a britânica Kelly Smith ou a brasileira Marta Vieira da Silva tivessem sido impedidas em sua infância e adolescência de jogar futebol, como seria o futebol feminino hoje? Temos certeza de que a trajetória de qualquer uma dessas grandes estrelas do futebol feminino mundial foi mais difícil do que a trajetória de qualquer outro grande jogador masculino, pelo simples fato do desafio dos preconceitos que ainda hoje o futebol feminino enfrenta. Basta verificar os salários, a projeção e a publicidade que ambas as categorias recebem para termos a certeza disso. Mas, se olharmos o futebol por si só, onde está o impedimento para que uma mulher o pratique? Não existe nada nele que forneça um argumento convincente sequer, ou seja, trata-se de machismo escancarado e revoltante para as garotas, que elas denunciam com razão. Maria Flor comenta sobre outras diferenças percebidas por conta do sexo, só que estas, grosso modo, 'favoreceriam' as garotas.

Tem professor que, só porque é menina, pode sair da sala, pode fazer o que quiser, e meninos não. Mas é porque ele está querendo ganhar a aluninha na conquistazinha. Então, por exemplo, se é uma menina bonitinha e pede pra sair da sala, 'ah, pode ir no banheiro'. Mas, se é menino, não pode. Dão mais liberdade para a menina, mas tem um alto preço. (Maria Flor - 10/09/2014)

A revelação de Maria Flor é preocupante, pois, no primeiro momento, pode parecer uma vantagem para as garotas menos avisadas, mas existe aí algo oculto muito perigoso. Um docente não pode, de forma alguma, favorecer um aluno em detrimento de outros e, no depoimento de Maria Flor, é explícita a intenção do docente: "ganhar a aluninha".

A nossa pergunta é: até que ponto o professor é capaz de ir com essa 'conquista'? E, se por acaso a aluna der a entender certo interesse por ele, qual a dimensão que isso poderá tomar? Se o professor já tem essa atitude, do que mais ele é capaz? Por mais que uma garota seja precoce, apresente um corpo com curvas de mulher e até já tenha uma vida sexual ativa, isso não dá abertura para que um adulto ultrapasse esse limite. No caso de envolver professor e aluna, então, a situação se agrava drasticamente. Dessa forma, não faz sentido algum o professor favorecer uma aluna em detrimento de um aluno, principalmente quando a questão está baseada em questões estéticas e que demonstram certos interesses afetivos/sexuais. 
Marina Castañeda (2006, p. 294) resume tudo isso de forma direta ao afirmar: "Tais benefícios aparentes criam sempre a dependência, e nunca se revelam tão permanente quanto as mulheres supõem que sejam". E é justamente nesse ponto que nos alertou Maria Flor ao concluir sua fala dizendo: "mas tem um alto preço". Esse alto preço está justamente ligado a esse 'benefício' aparente que não durará para sempre. O professor tem uma intenção ao favorecer a 'aluna bonitinha' e poderá 'cobrar' de alguma forma, mais cedo ou mais tarde. O benefício não será permanente, como bem disse Castañeda. Entendemos que a instituição educacional é a extensão da sociedade e, por mais que nela estejam fundadas as bases para a construção de uma nova organização social, ela infelizmente pode reproduzir manifestações desaprovadas ocorridas fora dos muros da escola. A nossa preocupação não está exatamente focada nessas reproduções ocorridas ali dentro, mas com qual intensidade elas ocorrem e se as devidas medidas são tomadas para que deixem de acontecer. Vejamos a fala de uma das entrevistadas:

\begin{abstract}
Teve uma menina que reclamou de assédio de professor e a primeira coisa que o coordenador perguntou foi: 'ela estava de blusinha, ou estava de uniforme?' [...]. Eles tampam os olhos totalmente para as nossas reclamações sobre assédio, sempre tentando justificar o professor, sempre tentando justificar a roupa que você estava [...]. Uma mãe falou esses dias: 'vocês estão esperando o quê? Que o professor passe a mão na bunda de uma menina, que abuse da menina dentro da sala? Aí vocês vão tomar alguma providência?'. Então assim, eles tratam como se não fosse nada, um professor mexe com as alunas há vinte anos. 'Ah vocês precisam de mais provas, ah vocês precisam de mais disso'. Gente, há vinte anos que as alunas estão reclamando o tempo inteiro de um professor, $e$ eles não fazem absolutamente nada? (Fernanda - 11/09/2014)
\end{abstract}

Percebam que a indignação de Fernanda é muito maior para a indiferença da coordenação em relação ao assunto do que propriamente para o assédio. Ela nem se debruça sobre o que o professor disse, onde exatamente foi dito e não manifesta seu ataque ao docente. A situação absurda para Fernanda se encontra na forma como a coordenação lida com o problema. Frisamos, antes de avançarmos sobre essa seara, que não pretendemos responsabilizar a coordenação e isentar o docente ou vice-versa, apenas analisamos a indignação da aluna para também levarmos esse assunto para outras esferas da instituição de ensino. Não podemos perder de vista que, onde houver uma prática intencional de educação, existirá um processo pedagógico, portanto a responsabilidade é de todos os indivíduos da escola. Segundo José Carlos Libâneo:

É quase unânime entre os estudiosos, hoje, o entendimento de que as práticas educativas estendem-se às mais variadas instâncias da vida social não se restringindo, portanto, à escola e muito menos à docência, embora essas devam ser a referência da formação do Periódicus, Salvador, n.12, v.1, nov.2019-abr.2020 - Revista de estudos indisciplinares em gêneros e sexualidades Publicação periódica vinculada ao Núcleo de Pesquisa NuCuS, da Universidade Federal da Bahia - UFBA ISSN: 2358-0844 - Endereço: http://www.portalseer.ufba.br/index.php/revistaperiodicus 
pedagogo escolar. Sendo assim, o campo de atuação do profissional formado em pedagogia é tão vasto quanto são as práticas educativas na sociedade. Em todo lugar onde houver uma prática educativa com caráter de intencionalidade, há aí uma pedagogia. (FIGUEIREDO, 2006, p.17)

Problemas de relacionamento entre docentes e discentes precisam ser aprovados por todas as instâncias hierárquicas da escola, e não somente ser uma prática considerada 'normal' para o docente. É necessário que esse profissional entenda que o que ele considera normal e uma brincadeira talvez seja ofensivo ao outro. É importante que exista essa preparação e compreensão do profissional de educação. E tratando-se da questão do assédio, que muitas vezes pode ficar no campo da interpretação, já que alguns dirão que é apenas uma brincadeira ou piada e outros não, o melhor a ser feito é jamais tecer comentário algum que abra precedentes para essa possibilidade. Vejamos o que Fernanda disse sobre o professor assediador - que está na escola há décadas - e sua amiga.

Toda vez que a Valentina entra na sala, o professor mede ela e chega a dar nojo [...]. Vira e mexe, quando ela está de decote, ele fica comentando, 'ah, tá calor, né? Você pode se tampar? Porque senão eu não vou conseguir parar de olhar pra isso!'. Uma vez, quando a gente estava na outra sala, ele falou: 'você pode tampar? Porque senão eu não vou conseguir me concentrar na aula'. Pra Valentina ele já falou várias coisas. (Fernanda - 11/09/2014)

É nítido o despreparo desse profissional, e a escola precisa oferecer subsídios para que profissionais como este se ajustem, se orientem e possam desempenhar seu verdadeiro papel dentro e fora de sala de aula. Não podemos ser maniqueístas a ponto de considerarmos que esse desvio de conduta do profissional seja ampliado para outras esferas de suas habilidades. Aqui, de forma alguma estamos analisando outra coisa que não seja a postura e o comportamento desse docente, assim, sua bagagem acadêmica não está em jogo e muito menos sendo questionada. A nossa preocupação, aqui, recai somente sobre seu comportamento em sala de aula e em sua relação com alunos e alunas. Segundo Figueiredo (2006, p. 24), “quando o profissional é bem orientado, a ação educativa acontece de uma maneira satisfatória. O professor bem orientado não elege um aluno com o qual ele se identifique e faz dele uma caricatura sua".

O profissional bem orientado comete menos deslizes, cria uma empatia pelo outro e passa a medir suas palavras durante suas explicações e exemplos. Ele identificará com maior facilidade os termos sexistas, homofóbicos, machistas e, muitas vezes, racistas que estão 
inseridos em nosso vocabulário cotidiano. Sabemos que essas medidas não se alteram da noite para o dia, por outro lado, compreendemos também que, se não fizermos nada, as coisas não se modificarão. Não para melhor!

É importante não esquecermos a nossa clássica forma de resistir ao novo, em mantermos as coisas como estão, principalmente quando não estamos sendo atingidos diretamente com os problemas apontados (e justamente por isso muitos defendem que o nosso país é conservador), mas não podemos perder de vista que a escola acompanha os avanços sociais e as reivindicações das instituições da sociedade civil.

Considerando essa questão, perceberemos que os movimentos feministas, LGBT+, negros, entre outros, avançaram significativamente nas últimas décadas em muitas questões e remodelaram as formas de organização da sociedade. Todo país foi orientado por conta dessas mudanças ocorridas nas esferas econômicas, jurídicas e sociais, e um profissional alinhado com as mudanças e conquistas ocorridas no espaço social nos últimos anos jamais cometeria a infelicidade descrita a seguir:

A gente estava falando sobre genética, e o professor: 'ah, a ervilha amarela estuprou a ervilha verde'. Como se fosse uma coisa pra você rir, uma coisa pra você dar risada. Eu queria que ele fosse estuprado! O quanto ele iria rir se ouvisse alguém tirando o sarro, banalizando isso? Porque não é uma coisa legal. (Valentina - 11/09/2014)

Temos certeza de que o profissional, ao dar este exemplo, não estava pensando literalmente em magoar ou desmerecer as meninas da sala e acreditamos que isso esteja tão naturalizado que ele certamente sempre deve ter feito esse tipo de comentário ao explicar essa aula. O que ocorre é que, agora, temos outra relação envolvendo os indivíduos, e a máxima do respeito ao próximo considerando sua identidade e subjetividade, deve, sim, ser levada em conta. Sabemos que isso é um exercício diário de autoavaliação crítica do profissional, mas, para que ele tenha essa capacidade, antes alguém precisará lhe fornecer as ferramentas necessárias para isso.

Ao relacionarmos esses resultados com os elementos teóricos discutidos, averiguamos que o relacionamento entre professor e aluna é uma estreita relação que engloba, além do conteúdo curricular exigido e aplicado nas escolas, questões de valores e crenças que são construídas durante uma vida toda. Verificamos que a escola, por ser parte orgânica de uma sociedade machista, não deixa de reproduzir essas mesmas práticas, e os professores dentro de sala de aula são aqueles que personificam essa estrutura. 
As afirmações, os comentários preconceituosos, a efetivação da hierarquia social reproduzida pelos professores nada mais são que uma reprodução, conforme nos apresentada Koehler (2002). Dessa forma, nossa observação com os relatos das garotas apenas corrobora com tudo o que foi exposto pelos teóricos nos quais nos baseamos.

Por esse motivo é tão necessário pensarmos o ambiente escolar de forma diferente. É de suma importância observarmos a escola como um ambiente que não está de acordo e muito menos favorece o bom relacionamento entre homens e mulheres e que impede e coage as meninas de maneira que muitos consideram natural.

Considerar a instituição escolar um ambiente pouco propício ao pleno desenvolvimento dos indivíduos que ali se encontram é o primeiro passo para rompermos com o silêncio que a naturalização do machismo nos impõe.

\section{1. (In)Salubridade do ambiente}

Considerando que tais ferramentas ainda não são oferecidas aos profissionais envolvidos diretamente com o corpo discente, teremos um quadro que certamente será desfavorável às meninas. Pois é impossível a uma garota, que por algum motivo adquiriu certo conhecimento sobre o quanto ela deve ser respeitada como pessoa, aceitar ou se sentir bem em um ambiente que a 'coisifica', que não permite sua fala e muito menos considera problemáticas atitudes de profissionais despreparados para lidar com as novas exigências da sociedade.

Observemos algumas falas para que possamos fazer esse exercício, a partir do questionamento: "Já ouviu ou sofreu assédio por parte de algum profissional da escola?"

\footnotetext{
Deste professor que eu disse. 'Veio de blusa cortada para mostrar o quê? Quer que todo mundo fique olhando o que você tem para mostrar?' Quando as meninas estão muito juntas, ele fica chamando as meninas de lésbica e fala que isso atiça os meninos. Isso ajuda a reproduzir o preconceito entre os próprios alunos, o preconceito, o machismo. Eu acho que é isso, o dever dele não é esse, o dever dele é fazer que isso não aconteça. O professor de [aqui ela disse a disciplina do professor que é o mesmo citado por Lara em seu depoimento] que assedia todo mundo, quando eu passo de costas, ele fala: 'nossa, hoje você está bonita heim?'. Mas com aquele 'comentariozinho' bem sarcástico, olhando para o bumbum. Ele já falou de mim para outros meninos: 'ah, você reparou nela hoje? Como ela está bonita'. Só de piadinhas deste tipo. (Maria Flor-10/09/2014)
}

Periódicus, Salvador, n.12, v.1, nov.2019-abr.2020 - Revista de estudos indisciplinares em gêneros e sexualidades Publicação periódica vinculada ao Núcleo de Pesquisa NuCuS, da Universidade Federal da Bahia - UFBA ISSN: 2358-0844 - Endereço: http://www.portalseer.ufba.br/index.php/revistaperiodicus 
É explícito o assédio denunciado por Maria Flor. A denúncia no caso dela parte de sua experiência pessoal, e não somente por observações ocorridas com outras garotas. Maria Flor inclusive baixou ainda mais o tom de voz - que já é baixo - ao nos dizer que o professor falava sobre a sua 'beleza' olhando para o seu bumbum. Seu constrangimento foi tamanho ao citar essa passagem que ela precisou não somente baixar o tom de voz, mas também abaixou a cabeça e desviou a direção do seu olhar para seus pés, e não mais diretamente para nós, como vinha fazendo. Portanto a resposta de Maria Flor é sim! Ela já sofreu assédio de algum profissional na escola e foi diretamente de um de seus professores. Vejamos o que disse Lara a esse respeito:

Tem um professor em específico que faz uns comentários extremamente invasivos e que você não faz nem pro seu amigo se ele não tiver dado permissão. Tem uma menina que tem um nome composto e o segundo nome dela é o de uma atriz pornô de um filme antigo famoso, e o professor falou pra ela que estava vendo aquele filme e lembrou dela. (Lara - 10/09/2014)

E a declaração de Valentina não é menos chocante do que a de sua amiga:

Já $o$ [falou o nome do professor. O mesmo já citado pelas outras amigas] principalmente, esse desgraçado. Uma vez ele estava falando sobre um texto sobre violência de namoro adolescente e esse cara não me pega e aponta para duas meninas negras na sala e: 'oh, vocês prestem atenção, porque vocês têm cara de quem vai apanhar do namorado [...]'. Além de racista, é machista, entendeu? [...]. As meninas ficaram quietas, isso é que eu tenho mais raiva! A sala ri, porque é um bando de otário babaca, entendeu? Isso é que me irrita, porque ele mexe justamente com quem não vai falar, justamente com a menina que está quietinha. (Valentina - 11/09/2014)

Lara e Valentina não apontam algo diretamente ligado a elas, mas apresentam denúncias de assédio e excessos cometidos por professores contra colegas de sala. Desse modo, Lara e Valentina já presenciaram e são testemunhas oculares desses abusos. Já Fernanda apresenta uma fala que conclui muito bem tudo isso e dá o gancho para nossa próxima pergunta, dizendo: "os meninos sempre apoiam estas atitudes do professor porque são as atitudes que eles têm também".

É uma situação lamentável e, como já tínhamos uma ideia prévia sobre o ambiente, formulamos uma pergunta que pudesse nos fornecer uma noção resumida do espaço em relação não somente aos professores, mas também aos alunos. O objetivo do nosso projeto era abordar as manifestações de assédio em todas as suas esferas, por isso perguntamos:

Periódicus, Salvador, n.12, v.1, nov.2019-abr.2020 - Revista de estudos indisciplinares em gêneros e sexualidades Publicação periódica vinculada ao Núcleo de Pesquisa NuCuS, da Universidade Federal da Bahia - UFBA ISSN: 2358-0844 - Endereço: http://www.portalseer.ufba.br/index.php/revistaperiodicus 
"Você já passou por alguma situação de assédio dentro do colégio por parte dos alunos? Qual tipo de assédio já sofreu?"

O ano passado, tinha alguns alunos aqui, só que eles eram aqueles caras mais velhos de trinta e quarenta anos. E quando eu e a Valentina ficávamos juntas, eles comentavam muitas coisas realmente, eles falavam coisas pra gente. E uma vez nós passamos no corredor e eles estavam sozinhos, e aí a gente ficou morrendo de medo. Porque assim, o corredor estava tudo vazio e os caras começaram a falar um monte de besteira, eu nem me lembro mais, porque já faz mais de um ano. E a gente chegou a reclamar pro coordenador, e aí ele falou que iria conversar com os caras, não sei o quê. Ficou tudo por isso mesmo e, até os caras saírem daqui, a gente não ficou livre disso. É que agora não tem mais esses homens velhos aqui, mas até eles saírem, a gente sofreu com isso. (Fernanda - 11/09/2014)

Aqui vemos uma denúncia que nos faz pensar para além da questão do assédio. A reflexão se dá no âmbito da estrutura organizacional do público escolar. Fernanda fala dos homens que faziam exclusivamente os cursos técnicos, sem relação alguma com a conclusão do ensino médio (como é o caso delas). Como claramente ela diz, os assédios por parte desses homens de trinta, quarenta anos só terminaram no ano seguinte, quando a escola eliminou esses cursos dos horários que os/as estudantes de ensino médio frequentavam a escola. Enquanto todos/as estavam misturados/as, a coordenação nada fez para que isso reduzisse, de acordo com sua fala.

Eu trabalhava com o Grêmio no começo do ano e isso implicava em entrar nas salas para passar recados. E em todas as salas que a gente entrava tinha piadinhas, tinha falas mais agressivas como se fossem cantadas de rua, só que na escola [...]. Sempre tinham as piadinhas, as cantadas, os assovios, e isso sempre me incomodou bastante. (Lara - 10/09/2014)

Lara diz que as cantadas recebidas dentro de sala de aula, quando entrava para transmitir os recados do grêmio, eram como cantadas de rua. Não precisamos entrar em detalhes quanto a isso, sabemos quão desrespeitosas são e, em muitos casos, de baixo calão as cantadas que ocorrem nas ruas. Talvez isso seja difícil de ser compreendido por um homem, mas a maioria das mulheres entenderá o desconforto de Lara. Agora, se você não é mulher, não necessariamente esse relato passará despercebido por você, basta um pouco de sensibilidade para entender a agonia de Lara e sua indignação.

Dizemos isso pois o incômodo de Lara não está só relacionado aos assédios que partem dos garotos em sala de aula, mas por eles não serem repreendidos pelo/a professor/a que está 
em sala. Mesmo isso não estando explícito em sua fala, é dessa forma que analisamos esse seu incômodo, pois, mesmo que Lara não tenha tido em nenhum momento a intenção de levantar essa reflexão, partimos do princípio de que a escola é um ambiente pensado e estruturado para oferecer conhecimento, transmitir valores, geralmente aceitos pela maioria, e ser um ambiente seguro e acolhedor.

Isso está presente em nosso consciente coletivo, faz parte de nossa cultura acreditarmos que a escola protege, acolhe e educa. Dessa forma, mesmo que inconscientemente, a indignação e o incômodo de Lara têm relação com esse fato também.

Quando eu venho de shorts ficam xingando, dizendo que eu estou querendo me mostrar, querendo dar e me chamando de gostosa. E quando, aconteceu no primeiro ano, o abuso fora da escola, os meninos ficaram zoando o que aconteceu e ficavam falando: 'ah, você gostou, você queria'. E o das garotas é bem pior do que os meninos. Acho que por as meninas não conhecerem muito o feminismo e o que ele tem a falar, elas falam muito. Eu conto essa minha história para muitas pessoas, para ser um exemplo do que pode acontecer com você, e eu ouço muito: 'você mereceu, você estava de saia, menina que fica bêbada não tem o que cobrar dos outros'. Eu já ouvi até que, por eu ter cabelo grande, eu não posso reclamar dos meninos mexerem comigo. É o cúmulo! E, porque eu ando com muitos amigos meninos, eu deixo todos se aproveitarem de mim. Os xingamentos das meninas são muito piores do que os dos meninos, porque parece que cria uma competição. Os meninos, mesmo, acham legal essa competição entre as meninas e botam fogo pra ver quem é a melhor assim. (Maria Flor - 10/09/2014)

Maria Flor, ao falar sobre isso, se mostrou muito decepcionada, principalmente quando disse que os ataques das meninas são piores que os dos garotos. Um ponto a ser observado em sua fala para além do assédio é quando ela diz que os meninos incentivam a competição e a rivalidade entre as garotas. Para uma garota que de alguma forma é alinhada com muitas das pautas feministas, tudo isso se torna muito mais decepcionante e desanimador. Pensando, então, em sentimentos, no estado emocional das meninas e em como elas literalmente se sentiam em relação a esses assédios, perguntamos: "como você se sente em relação a isso, saber de outras meninas que sofreram assédio ou mesmo você ter passado por isso?"

Eu me sinto invadida, desrespeitada, porque eles ignoram e sempre vão ignorar tudo o que eu falar. Teve um episódio que eu estava no auditório pedindo pro pessoal ficar quieto, fazer silêncio, porque estava sem microfone e tal, e começaram a assoviar naquela hora pra mim, porque só tinha eu lá na frente né. E isso me incomodou muito e me deixou muito, muito mal. Até que uma amiga me defendeu, levantou, gritou, mandou ir pra... Enfim, isso 
me faz pensar que eu sirvo só pra enfeitar eles, não sirvo pra aprender e passar nada, só pra servir de enfeite. (Lara - 10/09/2014)

Lara fala sobre invasão, desrespeito, coisificação. Sentimentos proporcionados pelos assédios coletivos inclusive, uma hostilidade tamanha que a deixou sem reação e incapaz de se defender; se não fosse pela amiga, os abusos continuariam por um tempo bem maior.

Eu acho que a escola, que é o lugar que a gente se sente mais seguro e a gente está aprendendo também a viver em sociedade, e a gente já presencia isso aqui dentro, de uma pessoa que deveria estar passando conhecimento e só está passando insegurança, passando medo. A gente nunca sabe o que vai acontecer! (Maria Flor - 10/09/2014)

Maria Flor externa o que falamos anteriormente sobre o ambiente escolar. Ela acredita na escola como um ambiente seguro e de aprimoramento do conhecimento, assim, encontrar um local insalubre e hostil é algo assustador e que não deveria ocorrer como ela bem nos disse.

Eu tenho vontade de bater nele com uma cadeira, falar que ele é ridículo [...]. E fiquei triste porque mostra como está a situação da escola pública, porque um professor que tecnicamente era pra ser um professor excelente, ele dá aula em faculdade, ele já deu aula em escola particular e tal, então a gente espera um comportamento de um profissional de qualidade, e você encontra uma pessoa que xinga os alunos de prostituta, entendeu? (Naomi - 11/09/2014)

Naomi fala sobre o professor que há vinte anos assedia alunas sem qualquer retaliação ou medida preventiva da escola.

Sim, eu fico muito desanimada e muito triste de pensar que a gente vive em uma sociedade que não tem como a gente mudar tão rápido assim. Se eu for um dia casar com um cara, vai ter situações que um dia ele vai ser machista pra cacete, se eu tiver uma filha, ele vai poder falar assim: 'ah, se você ficar com fulaninho, eu vou pegar uma arma'. Você fica muito desanimada. Por que eu vou continuar lutando, brigando, se ninguém tá nem aí, sabe? Mas aí a gente levanta a cabeça, não eu não posso deixar, porque senão ele vai fazer isso com as outras meninas, entendeu? Vai fazer isso com meninas que não tiveram oportunidade de aprender mais, sabe? Se eu tive essa oportunidade de aprender e entender, eu tenho que passar isso pra outras, porque, quanto mais meninas souberem, muito mais a gente consegue... Desanima, mas a gente vai levando. (Valentina - 11/09/2014)

Periódicus, Salvador, n.12, v.1, nov.2019-abr.2020 - Revista de estudos indisciplinares em gêneros e sexualidades Publicação periódica vinculada ao Núcleo de Pesquisa NuCuS, da Universidade Federal da Bahia - UFBA ISSN: 2358-0844 - Endereço: http://www.portalseer.ufba.br/index.php/revistaperiodicus 
Nervoso, tristeza e desânimo são os sentimentos de Naomi e Valentina ao depararem com essas manifestações, e Fernanda expressa asco e descrença nos seres humanos ao falar sobre isso. Vejamos o que ela disse:

Eu sinto bastante nojo desses homens e cada vez mais descrença na raça humana. Sinceramente eu gosto muito do feminismo, mas eu sinceramente não creio que isso um dia vai mudar, que um dia você vai passar na rua e os caras não vão mexer, que os caras vão controlar esses instintos, eu não acho que isso vai mudar. Então assim, eu sinto basicamente nojo, e eu acho que o mundo está cada vez mais perdido e que esses homens nunca vão mudar. Por mim, eu queria exterminar todos. (Fernanda-11/09/2014)

A análise geral a que chegamos é que essas manifestações não somente incomodam, elas paralisam as meninas. Mas a paralisação não é somente no sentido literal, como ocorreu com Lara quando ela se viu no centro de um assédio em massa, falamos aqui de todos os transtornos psicológicos que podem ocorrer por conta desses processos. A cultura abusiva instalada no ambiente escolar, como afirma Koehler (2002), promove a coisificação das meninas quando os relacionamentos interpessoais se concretizam e o desrespeito se torna regra dessa interação.

Após algumas poucas respostas, não há como negarmos que o ambiente escolar não seja assim tão agradável para as meninas e, mesmo que não tenhamos uma pesquisa abrangendo todo o universo feminino escolar, não podemos negar que os sentimentos dessas garotas e os fatos informados precisam ser levados em consideração para que uma escola melhor seja construída. Se não formos ensinados que o outro é a extensão do nosso eu, definitivamente muitas dessas práticas permanecerão, mesmo que consigamos elencar todas essas manifestações e relacioná-las com atos machistas e sexistas.

Feitos os apontamentos sobre algumas manifestações dentro da escola, outro ponto preocupante é tudo aquilo que se produz nas garotas. Não temos condições neste trabalho de demonstrar o quanto isso é danoso, mas podemos dizer e fazer uma analogia de que essas garotas vivem sob estado de terror, assustadas e com medo.

O imaginário do medo ocupa um espaço material no corpo, ou seja, tem uma inscrição corporal, porque, além de ser provocado por ameaças externas reais ou imaginárias às imagens da angústia original devida à emergência da consciência do Tempo e da Morte, e às experiências negativas advindas dessa consciência. (TEIXEIRA; PORTO, 1998, p. 54)

Periódicus, Salvador, n.12, v.1, nov.2019-abr.2020 - Revista de estudos indisciplinares em gêneros e sexualidades Publicação periódica vinculada ao Núcleo de Pesquisa NuCuS, da Universidade Federal da Bahia - UFBA ISSN: 2358-0844 - Endereço: http://www.portalseer.ufba.br/index.php/revistaperiodicus 
Considerando que o ambiente escolar possui em seu corpo um maior contingente feminino, temos aí um problema agravado, e esta é a prova de que temos um espaço permeado por regras e práticas machistas, pois, se em uma instituição cujo público, em sua maioria, está sob regras que o oprime, algo de errado existe aí.

Essa conclusão é corroborada por Figueiredo (2006, p. 44) ao afirmar que: "contudo, as mulheres são as que mais sofrem o assédio moral no trabalho. Esta informação é relevante porque no setor da educação como um todo há a predominância feminina”.

Não é à toa que, entre o contingente de depressivos, o público feminino é a maioria, assim como em relação a problemas de anorexia, bulimia, cefaleia e afins. Os males promovidos pelas mais diversas formas que o machismo pode se travestir são ainda desconhecidas em sua totalidade, mas não há como negar que as manifestações machistas em forma de assédio provocam males. E Figueiredo explica:

A vítima do assédio moral pode desenvolver uma infinidade de comportamentos que podem ser classificados como doenças advindas do estresse, que vão desde a área psicológica, como depressão e transtorno de ansiedade obsessiva generalizada, entre outras, até as doenças psicossomáticas e dependência química por álcool e outras drogas. (FIGUEIREDO, 2006, p. 43)

Quando analisamos as respostas das garotas e vemos em qual ambiente elas estão inseridas, indagamos o quanto de talentos perdemos e o quanto sufocamos mais da metade de nossas futuras gerações. Nossas garotas estão sendo aprisionadas e impedidas de se desenvolverem plenamente. O resultado disso foi denunciado no periódico PLOS One, pela antropóloga Kathryn Clancy (2014) da Universidade de Illinois Urbana-Champaign, em que ela aponta que o assédio sexual impede o avanço feminino no mundo científico. Vejamos abaixo o depoimento de Maria Flor quanto a esse impedimento.

Toda vez que a gente faz educação física, eu e mais muitas meninas, a gente fica com vergonha de fazer muita coisa que a professora pede, tipo alongamento, porque os meninos olham descaradamente, ficam olhando mesmo. E aí você não faz direito, perde nota por conta do olhar dos meninos, pois nós conseguiríamos fazer numa boa se eles não olhassem do jeito que olham e não ficassem fazendo piadinhas por trás. Isso tira o seu rendimento, tira a sua nota e a sua segurança de fazer isso direito. (Maria Flor - 10/09/2014)

Periódicus, Salvador, n.12, v.1, nov.2019-abr.2020 - Revista de estudos indisciplinares em gêneros e sexualidades Publicação periódica vinculada ao Núcleo de Pesquisa NuCuS, da Universidade Federal da Bahia - UFBA ISSN: 2358-0844 - Endereço: http://www.portalseer.ufba.br/index.php/revistaperiodicus 
Todo esse 'estado de terror psicológico' e medo rotineiro do cotidiano dessas garotas relacionado ao assédio resulta em desvantagem e impedimento de avançar em muitas áreas que, hoje, consideramos espaços masculinos. O grande responsável por isso é o machismo opressor naturalizado, transformado em medo e promovido pelo assédio, conforme constatamos nessas denúncias.

O medo é algo ambivalente. É ao mesmo tempo alguma coisa que o impele a avançar e alguma coisa que o puxa para trás; é alguma coisa que faz de você um ser duplo e que, quando você o exprime diante de um personagem junto de quem você quer dar mostras de ter medo, põe você a cada instante na postura de reflexo. (VANIER, 2006, p. 292)

Em um mundo cada vez mais carente de talentos e repleto de desafios, onde o Brasil ainda é um dos principais países emergentes e capazes de fornecer alternativas para diversos problemas globais, eliminar mais da metade de nosso contingente com práticas tão arcaicas é realmente optar pelo atraso, como Moraes e Belizário afirmam:

Quando um grupo não acredita na capacidade de qualquer um dos outros grupos humanos ele se fecha, condena a possibilidade de melhora da relação e consequentemente põe em risco a sua própria existência. (MORAES; BELIZÁRIO, 2005, p. 41)

Os homens não podem continuar oprimindo as mulheres e permanecerem acreditando que essa opressão não lhes fará mal também. Respeitar e valorizar o próximo - neste caso, as mulheres - é uma questão de sobrevivência para os próprios homens.

\section{Considerações finais}

Justamente por isso consideramos deletério e celerado o discurso que enfatiza a não discussão desse tema nas escolas, pois, se somos um país conservador, como afirmou o presidente, deduzimos, a partir de nossa história, que as mulheres têm lugares definidos e limitados para ocupar na sociedade, e de maneira alguma esses lugares estão em pé de igualdade com os espaços ocupados pelos homens.

Não podemos permanecer pensando a educação como uma prática que vigore de forma excludente e unilateral. Precisamos orientar o ensino para a formação de indivíduos conscientes, questionadores e com senso crítico capaz de questionar inclusive privilégios secularmente estabelecidos. 
A discussão e a aplicação de um convívio verdadeiramente respeitoso entre homens e mulheres dentro da escola, sem sombra de dúvida, é um dos principais passos para eliminarmos inúmeras injustiças, organizarmos um futuro muito mais promissor para a sociedade e, acima de tudo, valorizarmos as mulheres como elas de fato realmente merecem. Isso acontecendo, certamente atingiríamos um patamar nas relações sociais que, até o presente momento, estamos muito longe de alcançar, mas, se conseguíssemos, estabeleceríamos a partir de então um novo estágio na história da humanidade.

\section{Referências}

ASSIS, S. G.; AVANCI, J. Q. Labirinto de espelhos. formação da auto-estima na infância e na adolescência. Rio de Janeiro: Fiocruz, 2004.

BALDAN, M.; FREITAS, N. A. Dossiê Escola sem Partido e formação humana. Fênix - Revista de História e Estudos Culturais, Uberlândia, v. 14, ano 14, n. 1, p. 1-8, 2017. Disponível em: http://bit.ly/2IGVrYi. Acesso em: 15 jan. 2019.

CASTAÑEDA, M. O machismo invisível. São Paulo: A Girafa, 2006.

CLANCY, K. B. H. et al. Survey of Academic Field Experiences (SAFE): Trainees Report Harassment and Assault. PLOS ONE, San Francisco, v. 9, n. 7, p. e102172, 2014. Disponível em: http://bit.ly/39TyJrO. Acesso em: 2 fev. 2020.

FALUDI, S. Backlash: o contra-ataque na guerra não declarada contra as mulheres. Rio de Janeiro: Rocco, 2001.

FIGUEIREDO, W. S. Assédio moral na escola pública: um problema de saúde numa visão libertária. Rio de Janeiro: Achiamé, 2006.

GERHARDT, E.; SILVEIRA, D. T. Métodos de pesquisa. Porto Alegre: Editora da UFRGS, 2009. Disponível em: http://bit.ly/3cYL1Ry. Acesso em: 29 ago. 2014.

KOEHLER, S. M. F. Violência psicológica: um estudo do fenômeno na relação professor-aluno. São Paulo: Edusp, 2003.

MACEDO, R. M. A.; BOMFIM, M. C. A. Um olhar sobre juventudes e violências na escola. Teresina: Expansão, 2007.

MINAYO, M. C. S. (org.). Pesquisa social: teoria, método e criatividade. Petrópolis: Vozes, 2001.

MORAES, L.; BELIZÁRIO, L. V. Diversidade humana nas empresas. uma questão de competitividade ou de responsabilidade. Rio de Janeiro: Papel Virtual, 2005.

"QUEM ENSINA sexo é papai e mamãe e acabou". O Dia, Rio de Janeiro, 10 nov. 2018. Disponível em: http://bit.ly/33jgKZb. Acesso em: 24 jan. 2019.

TEIXEIRA, M. C. S.; PORTO, M. R. S. Violência, inseguranças e imaginário do medo. Cadernos Cedes, Campinas, v. 19, n. 47, p. 51-66, 1998.

VANIER, A. Tem medo do que? Ágora, Rio de Janeiro, v. 9 n. 2 p. 285-298, 2006. Disponível em: http://bit.ly/33hgE4i. Acesso em: 15 out. 2014.

VIANNA, C.; RIDENTI, S. Relações de gênero e escola: das diferenças ao preconceito (diferenças e preconceito). São Paulo: Summus, 1998.

WALKERDINE, V. O raciocínio em tempos pós-modernos. Educação e Realidade, Porto Alegre, v. 20, n. 2, p. 207-226, 1995.

WOLF, N. $O$ mito da beleza: como as imagens da beleza são usadas contra as mulheres. Rio de Janeiro: Rocco, 1992. 